\title{
Thermal and Microstructure Analysis of Cocofoam Made from Blended Coconut Fiber with Latex Compound
}

\author{
I.D.K. Anom ${ }^{1}$, Bambang Setiaji ${ }^{2}$, Wega Trisunaryanti ${ }^{2}$, Triyono ${ }^{2}$
}

\begin{abstract}
Thermal and microstructure analysis of cocofoam made from vulcanized coconut fiber and latex compound were conducted. The cocofoam was produced by blending coconut fiber and latex compound with weight ratio of 10/25 (CF5-1) and 20/55 (CF5-2) at room temperature. The cocofoam characters were then analyzed by Scanning Electron Microscope (SEM), Thermogravimetric Analysis (TGA) and Differential Scanning Calorimetry (DTA) instruments. The result showed that the increase of coconut fiber and latex compound ratio produced a higher density of cocofoam. The highest value density was $0.6920 \mathrm{~g} / \mathrm{cm}^{3}$ with flexibility of $90 \%$ produced by the CF5-2 sample. The SEM analysis showed that both specimens surface of the CF5-1 and CF5-2 samples have different pores size and the latex compound is not distributed thoroughly in the cocofoam. The thermal analysis showed that the production of cocofoam was largely determined by latex compound that served as fiber binder matrix. Cocofoam started to degrade at the temperature of $90^{\circ} \mathrm{C}$ and was damaged when it was heated at the temperature of $115^{\circ} \mathrm{C}$ for 2.5 hours.
\end{abstract}

Keywords: Cocofoam, latex compound, coconut fiber, Scanning Electron Micro (SEM), Thermal Analysis

\footnotetext{
${ }^{1}$ Department of Chemistry, Faculty of Mathematics and Natural Sciences, Manado State University, Indonesia. Email: dewaanom10@gmail.com

${ }^{2}$ Department of Chemistry, Faculty of Mathematics and Natural Sciences, Universityof Gadjah Mada, Yogyakarta, Indonesia.
} 


\section{Introduction}

The use and optimalization of natural polymers such as coconut fiber and latex have been widely developed. The increasing interest on these two materials is manifested by their rising use on household activities ranging from small-scale industries to middle-scale industries. Coconut fiber becomes the main priority due to its ability to degrade in the nature, and its renewable characteristics. Further, Indonesia has abundant natural fibers, such as cotton, kapok, jute, Sisal (Agave Sisalana), kenaf (Hibiscus cannabinus), banana, coconut fiber, palm fiber, raw ramie fiber and fine ramie fiber that became the main accelerating factor to the emerging use of fiber and latex composite [1].

Coconut fiber and latex are natural polymers from which a new product named cocofoam is made as the result of those materials' blending. Cocofoam is classified as a composite with high elasticity and resilience, therefore, it can perfectly function as alternative material to natural latex foam and synthetic foam. Cocofoam made from natural ingredient has bigger pore than synthetic foam making its surface cold and comfortable. As a result, this characteristic eventually marks its advantage over other materials. The technology in composite has undergone rapid development nowadays. This visible shift of technology trend is due to the fact that natural-fiber reinforced composite is more eco-friendly than syntheticfiber reinforced composite. Besides, natural fiber has more strengths, low density, cheap, and can be biologically decomposed $[2,12]$. Reinforcing substance is an ingredient whose main physical characteristic is useful to add the strength of composite. Usually, natural fiber and synthetic fiber are used as reinforcing substances [3]. Today, coconut fiber becomes the most essential material in the making of geo-textile, car seat, roof, carpet, mattress, and other products of household industries $[4,5,6]$.

Coconut fiber is one of natural fiber sources that functions an alternative material of composite. Coconut fiber has widely-open potential to be developed as composite product having high commercial value. Indonesia has abundant source of coconut fiber. The average rate production of coconut trees in Indonesia reaches 15.5 trillion/year, therefore, it produces 1.8 million tons coconut fiber. This abundant raw materials have not been optimally transformed into high economical value products $[5,6]$.

Those background above, thus, become the main reason for conducting this research whose primary goal is to produce one natural composite or cocofoam from the mixing of coconut fiber and latex compound. Coconut fiber serves as reinforcing agent meanwhile latex compound serves as matrix to form the bond among fibers. It is expected that the result of this research is applicable in the manufacturing process of cocofoam in either small or middle scale industries in Indonesia.

\section{Materials and Methods}

\section{A. Materials}

Coconut fiber obtained from PT Tropica Nucifera Industry, Bantul, Yogyakarta and liquid latex brand 'Cap Jempol' obtained from Toko Liman, Malioboro, Yogyakarta. Potassium oleat, Potassium Hidroxide, Zinc diethyldithiocarbamate (ZDEC), Zinc Mercaptobenzothiazole (ZMBT), Butylated Hydroxytoluene (BHT), and Sulfur were obtained from PT Bratako, Yogyakarta.

\section{A. Equipment}

- $\quad$ Standard glass equipment

- Analytical scale AND GR-200 SER. 14214919 Japan

- $\quad$ Magnetic stirrer

- Oven Memmert 854 Schwabach Tel. $09122 / 4031 \quad 0-24$ hour $220^{\circ} \mathrm{C}$ Western Germany, Jeol JSM

- 6360LA analytical Scanning Electron Microscope

- Tokyo Testing Machine MF6 Co. Ltd. Tokyo-Japan

- $\quad$ Template and One Set Compressor. 


\section{Methods}

\section{Preparation of Coconut Fiber}

The first step was to separate coconut fiber from dirt and dust in order to get clean coconut fiber. Then, this fine fiber was washed using water, and dried up under the sunlight. The fiber was then twisted before heated in the oven under the temperature of $95^{\circ}-100^{\circ} \mathrm{C}$ for approximately 6 hours, then cooled down under room temperature for 2-3 days. A ball of twined fiber was re-opened in order to get a spiraled shape fiber.

\section{Preparation of Latex Compound}

Latex used in this research was cleaned to remove rough particles such as dust and sand. All chemical substances are dissolved into liquid latex. The composition of chemical substances was $100 \mathrm{~g}$ of liquid latex, $2 \mathrm{~g}$ of Potassium Oleat solution $20 \%, 3 \mathrm{~g}$ of $\mathrm{KOH}$ solution $10 \%, 2 \mathrm{~g}$ of ZDEC solution $50 \%, 2 \mathrm{~g}$ of ZMBT solution $50 \%, 4 \mathrm{~g}$ of $\mathrm{ZnO}$ solution $50 \%, 1 \mathrm{~g}$ of BHT solution $50 \%$ and $3 \mathrm{~g}$ of Sulfur solution $50 \%$. Latex compound mixed with all solutions is stirred by using magnetic whisk for 30 minutes. Then, this ingredient is kept for 2 days before it is ready to use.

\section{Preparation of Cocofoam}

Coconut fiber was spread over wooden plate (length $\mathrm{x}$ width $\mathrm{x}$ height $=24 \times 15 \times 5 \mathrm{~cm}$ ). This coconut fiber should be well-managed in the plate. The fiber surface was evenly sprayed by latex compound with the distance between fiber surface and nozzle sprayer was approximately $20 \mathrm{~cm}$. The initial spraying of latex compound was 1/3 part of overall dosage. The blend of coconut fiber and latex compound began with oven heating in the temperature of $80-90^{\circ} \mathrm{C}$ for $15-20$ minutes. Then, cocofoam was taken out from the oven and cooled down for several minutes before having sprayed with $2 / 3$ remaining part of compound with the distance with nozzle spray was $5 \mathrm{~cm}$. Cocofoam was taken out from the plate then vulcanized for the second time in the oven, shaped it and labeled with CF5-1. The preparation of cocofoam CF5-2 has similar process with that of the cocofoam CF5-1.

\section{Physical and Mechanical Testing of Cocofoam}

The assessment process of physical and mechanical natures includes its density, bending, micro structure analysis (SEM) and thermal analysis (DTA/TGA).

\section{Results and Discussion}

The results showed that the increase of weight ratio of coconut fiber and latex compound which was made in constant volume increased the density. The ratio of coconut fiberlatex compound: 10/21 (CF5-1) and 20/55 (CF52) with density value in a row is $0.6032 \mathrm{~g} / \mathrm{cm}^{3}$ and $0.6920 \mathrm{~g} / \mathrm{cm}^{3}$. The cocofoam with density of $0.6032-0.6920 \mathrm{~g} / \mathrm{cm}^{3}$ was classified into high density cocofoam. The difference in cocofoam's density was the result of the higher weight ratio of fiber and latex compound while the volume of cocofoam did not show any increase. Thus, it caused the higher density of cocofoam. The density of some different fibers which were produced from the same source, lignocellulosic fiber, has significant influence over semi-raw material. Every material used the same matrix so that the different density was the result of the kind of fibers used in the experiment, the absorption between matrix and fibers, as well as the fiber's pores [7]. Some researchers had undergone an experiment on latex foam which explores the fact that latex foam made of natural rubber have density from 0.20 to $0.4 \mathrm{~g} / \mathrm{cm}^{3}$ and compression value more than $25 \%$. The result of this experiment was not considered as fulfilling requirements to be technical latex foam because the ideal latex foam has density less than 0.2 and its compression value should not exceed $25 \%$. Micro structure examination of pored polymers such as high density latex showed that the relative density ranges from $0.4-0.8[8,9,10$, 13].

Compression is one of parameters commonly used in elasticity test of cocofoam product. Elasticity refers to the manner in which particular material responds to strain or external load over a given unit area. Load given over certain unit area during compression test is static load which is held in a fixed position for a specific amount of time. The variation of pressures will directly give impact to bending 
force since compact tension will significantly increase the specimen's bending force [11]. The result of compression test on the changes of cocofoam width was presented in table 1, 2, 3, and 4.

The results of compression test $50 \%$ presented in Table 1 and Table 2 reveal that the compression value of CF5-1 and CF5-2 ranges from $5.93 \%$ to $10.00 \%$, meanwhile compression value of CF5-2 ranges from $3.60 \%$ to $8.40 \%$. The mean of CF5-2 compression value was lower than that of CF5-1. It means that the lower the compression value the more elastic cocofoam. This condition happened because the higher ratio of fiber and latex compound caused the density of cocofoam to significantly increase. Further, the higher amount of fiber used in this experiment as reinforcing agent added the strength of cocofoam to hold the load.

The compression value of CF5-1 on the fixed compression $80 \%$ (Table 3) ranges from $8.47 \%$ to $22.13 \%$ meanwhile the compression value of CF5-2 (Table 4) ranges from $8.00 \%$ to $19.07 \%$. The addition of compression from $50 \%$ to $80 \%$ causes the higher compression values of CF5-1 and CF5-2. It means that the decrease in strength and thickness of cocofoam was due to the duration of compression and the weight of load given.

Figure 1 showed the relationship between compression duration and the change in the thickness. It can be inferred that fixed compression test of $50 \%$ and $80 \%$ had specific purpose to figure out some extreme characteristics and to provide a prediction on the long-term use of cocofoam. If compression is heightened, all pores in cocofoam will have more density which eventually decreases the volume of cocofoam and strengthens the density of cocofoam. Changes in cocofoam's thickness refer to changes in particles' shape because temporary load pressure. It will return to former shape when there is no pressure. Compressive strength was the reverse of pushing force and it was the capacity of a material to withstand before it crushes. [15].

Based on compression value, cocofoam CF5-1 and CF5-2 can be classified into products with good elasticity because their compression values were lower than latex foam's compression value. In other words, cocofoam's compression value fulfills the requirement that industries yield. The lower the compression value, the stronger and more elastic cocofoam was produced. The product of latex foam mattress needed by the industry must be resistant to high temperature $\left( \pm 100^{\circ} \mathrm{C}\right)$ and has good compression value at maximum $25 \%$. Latex foam was made of latex mechanical foaming or liquid latex, then those polymers were mixed tightened in its swelling state $[8,14]$.

Based on SEM analysis, Morphology of cocofoam which was resulted from coconut fiber and latex compound at the ratio of 10/25 (CF5-1) and 20/55 (CF5-2) were presented in Figure 2a and $2 b$.

The surface morphology of cocofoam CF5-1 and CF5-2 shown in figure $2 a$ and $2 b$ indicated that latex compounds were not evenly distributed on its surface so that the thickness of latex which covers and binds fibers was different. The pores sizes were different and incongruent because of different length of fiber. It was shown that the result of the different size of spiraled-shape fiber. The difference in density of CF5-1 and CF5-2 did not show any significant impact on morphology because coconut fiber and latex compound trapped in cocofoam were not evenly distributed which eventually made the micro structures of CF5-1 and Cf5-2 looked similar.

\section{Thermal Analysis}

The results of the Thermal Analysis using TGA/DTA for CF5-1 are shown in Figure 3a, and for CF5-2 in Figure 3b. Figure 3a was TGA/DTA measurement for cocofoam CF5-1 whose mass ratio between coconut fiber and latex compound was $10 / 25$. The TGA curve showed that thermal characteristics of cocofoam made of coconut fiber and latex compound depends on latex compound thermal characters. It was shown that at the temperature of $278^{\circ} \mathrm{C}$ the curve was smooth which means that latex compound limits cocofoam to serve only as matrix. When meticulously examined, the curve showed that the cocofoam mass decreased begun 
Table 1. Data on fixed compression test $50 \%$ of cocofoam CFC-1

\begin{tabular}{|c|c|c|c|c|}
\hline \multirow{2}{*}{ Time (Hour) } & \multirow{2}{*}{$\begin{array}{c}\text { Weight } \\
\text { (kg) }\end{array}$} & \multicolumn{2}{|c|}{ Cocofoam CF5-1 } & \multirow{2}{*}{$\begin{array}{c}\text { Cocofoam } \\
\text { Compression } \\
\text { Value }(\%)\end{array}$} \\
\hline & & $\begin{array}{c}\text { Initial } \\
\text { Thickness (cm) }\end{array}$ & $\begin{array}{c}\text { Final Thickness } \\
(\mathrm{cm}, \%)\end{array}$ & \\
\hline 1 & 4.40 & 5.00 & $4.70(94.07)$ & 5.93 \\
\hline 2 & 4.20 & 5.00 & $4.67(93.40)$ & 6.60 \\
\hline 3 & 4.60 & 5.00 & $4.60(92.00)$ & 8.00 \\
\hline 4 & 4.40 & 5.00 & $4.50(90.00)$ & 10.00 \\
\hline
\end{tabular}

Table 2. Data on fixed compression test $50 \%$ of cocofoam CFC-2

\begin{tabular}{|c|c|c|c|c|}
\hline \multirow{2}{*}{ Time (Hour) } & \multirow{2}{*}{$\begin{array}{c}\text { Average } \\
\text { Weight } \\
\text { (kg) }\end{array}$} & \multicolumn{2}{|c|}{ Cocofoam CF5-2 } & \multirow{2}{*}{$\begin{array}{l}\text { Cocofoam } \\
\text { Compression } \\
\text { Value }(\%)\end{array}$} \\
\hline & & $\begin{array}{c}\text { Initial } \\
\text { Thickness (cm) }\end{array}$ & $\begin{array}{c}\text { Final Thickness } \\
(\mathrm{cm}, \%)\end{array}$ & \\
\hline 1 & 4.50 & 5.00 & $3.60(96.40)$ & 3.60 \\
\hline 2 & 4.40 & 5.00 & $3.73(96.27)$ & 3.73 \\
\hline 3 & 4.90 & 5.00 & $7.52(92.47)$ & 7.53 \\
\hline 4 & 5.20 & 5.00 & $8.40(91.60)$ & 8.40 \\
\hline
\end{tabular}

Table 3. Data on fixed compression test $80 \%$ of cocofoam CFC-1

\begin{tabular}{|c|c|c|c|c|}
\hline \multirow{2}{*}{ Time (Hour) } & \begin{tabular}{c} 
Average \\
Weight \\
\cline { 3 - 4 }
\end{tabular} & \multicolumn{2}{|c|}{ Cocofoam CF5-1 } & $\begin{array}{c}\text { Cocofoam } \\
\text { Compression } \\
\text { Value (\%) }\end{array}$ \\
\cline { 3 - 4 } & 198.60 & $\begin{array}{c}\text { Initial } \\
\text { Thickness (cm) }\end{array}$ & $\begin{array}{c}\text { Final Thickness } \\
\text { (cm, \%) }\end{array}$ & \\
\hline 1 & 154.10 & 5.00 & $4.58(91.53)$ & 8.47 \\
2 & 200.10 & 5.00 & $4.13(82.53)$ & 17.47 \\
3 & 145.50 & 5.00 & $4.03(80.67)$ & 19.33 \\
4 & \multicolumn{2}{|c}{} \\
\hline
\end{tabular}

Table 4. Data on fixed compression test $80 \%$ of cocofoam CFC-2

\begin{tabular}{|c|c|c|c|c|}
\hline \multirow{2}{*}{ Time (Hour) } & \multirow{2}{*}{$\begin{array}{c}\text { Average } \\
\text { Weight } \\
\text { (kg) }\end{array}$} & \multicolumn{2}{|c|}{ Cocofoam CF5-2 } & $\begin{array}{c}\text { Cocofoam } \\
\text { Compression } \\
\text { Value (\%) }\end{array}$ \\
\cline { 3 - 4 } & $\begin{array}{c}\text { Initial } \\
\text { Thickness (cm) }\end{array}$ & $\begin{array}{c}\text { Final Thickness } \\
\mathbf{( c m , \% )}\end{array}$ & \\
\hline 1 & 129.90 & 5.00 & $4.60(92.00)$ & 8.00 \\
2 & 189.90 & 5.00 & $4.42(88.40)$ & 11.60 \\
3 & 248.80 & 5.00 & $4.36(87.20)$ & 12.80 \\
4 & 153.50 & 5.00 & $4.04(80.93)$ & 19.07 \\
\hline
\end{tabular}


Figure 1. Relationship between compression duration and compression value of cocofoam during fixed compression $50 \%$ and $80 \%$

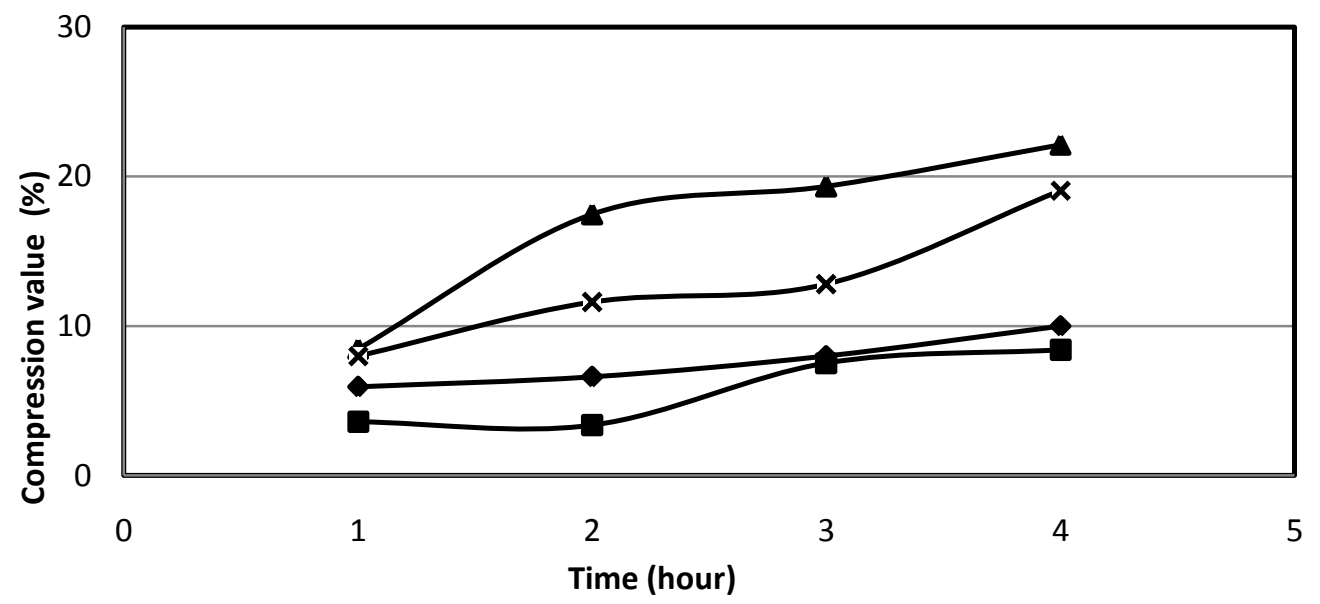

$\neg$ CF5-1 Com.50\% -CF5-2 Com.50\% $\rightarrow$ CF5-1 Com.80\% - - CF5-2 Com.80\%

Figure 2. Cocofoam SEM Micrograph: (2a) ratio coconut fiber/latex compound $10 / 25$ and (2b) ratio coconut fiber/latex compound 20/55

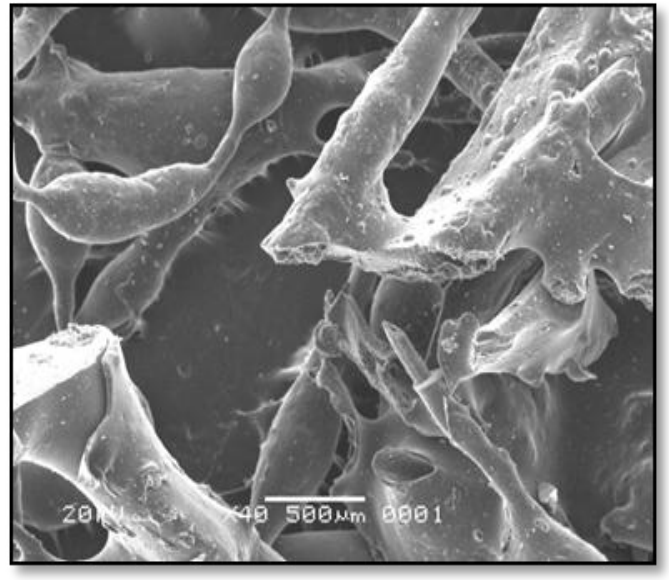

(2a, CF5-1)

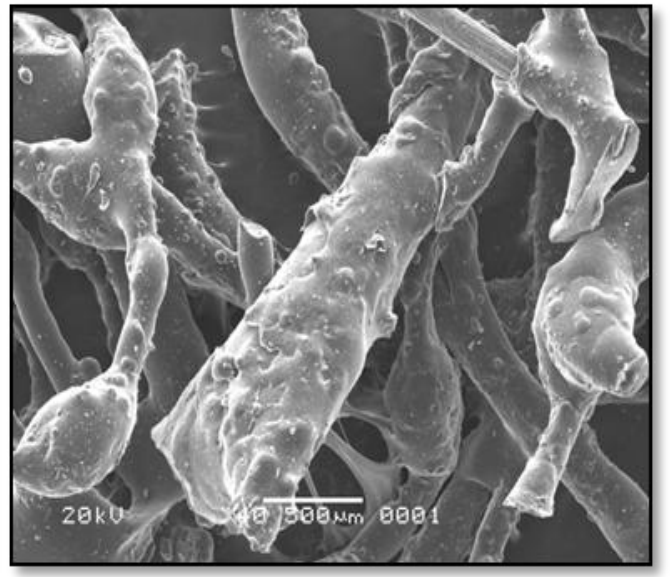

(2b, CF5-2) 
from temperature of $90^{\circ} \mathrm{C}$ to $278^{\circ} \mathrm{C}$. The phenomena indicated that latex compound contained in cocofoam was degraded even though in a small amount.

DTA curve showed three endothermic peaks. The first endothermic peak came from solvent evaporation at the temperature of $278^{\circ} \mathrm{C}$. The second endothermic peak probably came from the evaporation of additive substance at the temperature of $380^{\circ} \mathrm{C}$. The third endothermic peak showed the evaporation of latex contained in cocofoam at the temperature of $505^{\circ} \mathrm{C}$. DTA curve showed that CF5-1 endothermic peak was getting steepy because the number of latex trapped inside cocofoam was decreased. Meanwhile, the curve's peak has widened because the number of fiber inside cocofoam was increased which required more energy for evaporation.

Figure $3 b$ was the result of TGA/DTA measurement for cocofoam CF5-2 with mass ratio between coconut fiber and latex compound 20/55. The TGA curve showed that cocofoam made of coconut fiber and latex compound was influenced by the thermal characteristics of latex compound. In curve TGA of CF5-1 and CF5-2, it was clearly observed that the curve steepness began at the temperature of $90^{\circ} \mathrm{C}$ up to $250^{\circ} \mathrm{C}$ when the latex compound starts to degrade. Although its change was not too visible, this datum becomes significant in the process of making composite by using latex vulcanization process. Regarding data collected by the researcher [16], DTA curve showed that natural rubber melts at the temperature of $181.17^{\circ} \mathrm{C}$, and it could be inferred that the swelling process of natural rubber through heating process happened at the temperature of $181.17^{\circ} \mathrm{C}$. Further, DTA curve also revealed that there are three endothermic peaks. The first endothermic peak at the temperature of $300^{\circ} \mathrm{C}$ was happened because of the evaporation of solvent agent during the preparation process of cocofoam. The second endothermic peak at the temperature of $385^{\circ} \mathrm{C}$ was happened because of the evaporation of additive substance during the preparation process of cocofoam. The third endothermic peak at the temperature of $480^{\circ} \mathrm{C}$ was happened because of the evaporation of latex trapped inside cocofoam. From this thermal analysis, it can be concluded that the preparation of cocofoam greatly depends on the characteristics of latex compound used. The strength and the elasticity of cocofoam was decreased due to the degradation which was started at the temperature of $90^{\circ} \mathrm{C}$ causing the cocofoam to break when peak temperature of $181.71^{\circ} \mathrm{C}$ was reached.

\section{Conclusion}

At the fixed volume, the increased ratio of the blending between coconut fiber and vulcanized latex compound resulted in cocofoam with higher mass density, as shown in cocofoam samples with ratio 10/25 (CF5-1) that has mass density $=0.6032 \mathrm{~g} / \mathrm{cm}^{3}$ and ratio 20/55 (CF5-2) that has mass density $=0.6920 \mathrm{~g} / \mathrm{cm}^{3}$. The result of fixed compression test $50 \%$ and $80 \%$ showed that cocofoam has lower average of compression test than natural rubber mattress ( $\max 25 \%)$ which means that cocofoam has better elasticity compared to natural rubber. The density or cocofoam mass type CF5-1 and CF5-2 did not show significant micro structure differences because coconut fiber and latex compound were evenly distributed that resulted to a similar morphology of CF5-1 and CF5-2. From thermal analysis, it can be concluded that the quality of cocofoam was determined by the characters of latex compound used. Cocofoam started to degrade at the temperature of $90^{\circ} \mathrm{C}$ and it was busted and out of use after heating at the temperature of $115^{\circ} \mathrm{C}$ for 2.5 hours. 
Figure 3a. Cocofoam TGA and DTA curves: ratio coconut fiber/latex compound 10/25

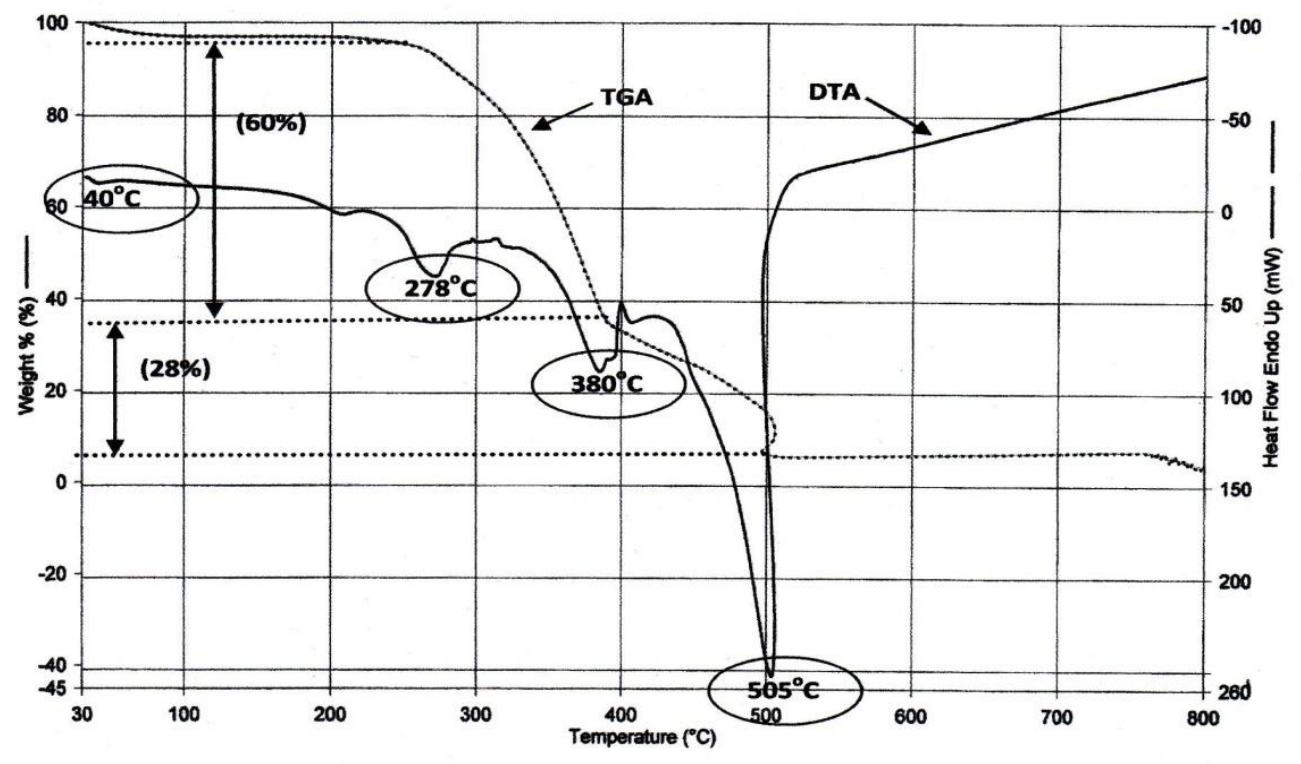

Figure 3b. Cocofoam TGA and DTA curves: ratio coconut fiber/latex compound 20/55

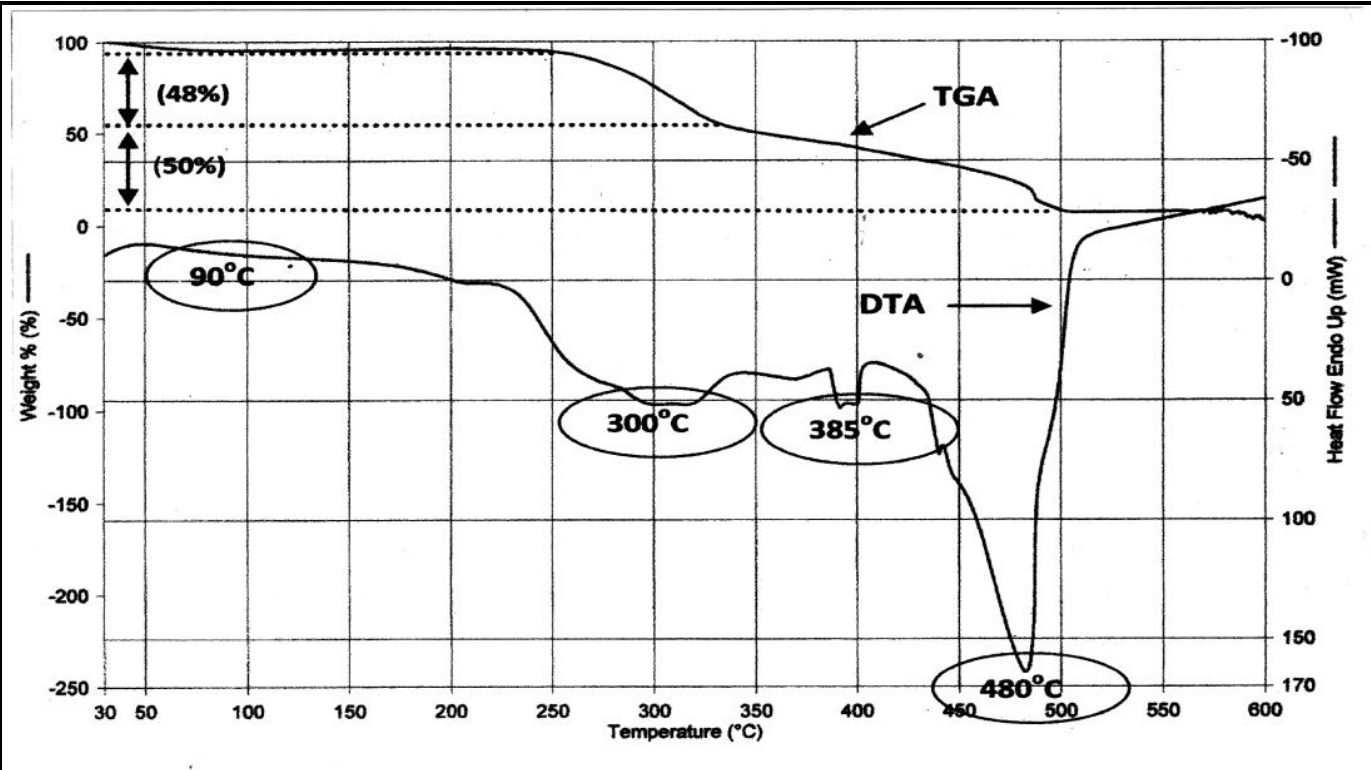




\section{References}

[1] Boimau, K. 2010. Pengaruh Fraksi Volume dan Panjang Serat Terhadap Sifat Bending Komposit Poliester yang Diperkuat Serat Batang Pisang, Seminar Nasional Tahunan Teknik Mesin (SNTTM) ke-9, Palembang 13-15 Oktober 2010.

[2] Diharjo, K. 2006. Pengaruh Perlakuan Alkali terhadap Sifat Tarik Bahan Komposit Serat Rami-Polyester, Jurnal Teknik Mesin, 8 (1), 8-13.

[3] Hadiyawarman, A. Rijal, B.W. Nuryadin, M. Abdullah and Khairurrijal. 2008. Fabrikasi Material Nanokomposit Superkuat, Ringan and Transparan Menggunakan Metode Simple Mixing, Jurnal Nanosains \& Nanoteknologi, 1 (1), 14-21.

[4] Sudarsono, T. Rusianto and Y. Suryadi. 2010. Pembuatan Papan Partikel Berbahan Baku Sabut Kelapa dengan Bahan Pengikat Alami (Lem Kopal), Jurnal Teknologi, 3 (1), 22-32.

[5] Mahmud, Z. and Y. Ferry. 2005. Prospek Pengolahan Hasil Samping Buah Kelapa. Jurnal Perspektif, 4 (2), 55-63.

[6] Arbintarso, E.S. 2009. Tinjauan Kekuatan Lengkung Papan Serat Sabut Kelapa Sebagai Bahan Teknik, Jurnal Teknologi, 2 (1), 53-60.

[7] Maulida. 2008. Pembuatan Komposit Termoplastik Berdasarkan Serat Kelapa Sawit dengan Kaedah Pragpreg, Jurnal Penelitian Rekayasa, 1 (2), 74-79.

[8] Anggaravidya, M. 2008. Pengaruh Jenis Blowing Agent Terhadap Sifat Fisik Busa Karet, M.P.I., 2 (3), 277-283.

[9] Mills, N.J. 2007. Polymer Foam Handbook: Engineering and Biomechanics Applications and Design Guide, Butterworth - Heinemann: Elsevier, burlington.
[10] Najib, N.N., Z.M. Ariff, N.A. Manan, A.A. Bukar and C.S. Sipaut. 2009. Effect of Blowing Agent Concentration on Cell Morphology and Impact Properties of Natural Rubber Foam, J. Phys. Sci., 20 (1), 13-25.

[11] Rusianto, T., and L.D. Setyana. 2005. Pengaruh Kadar TiO2 Terhadap Kekuatan Bending Komposit Serbuk Al/TiO2, Jurnal Teknik Mesin, 7 (1), 28-34.

[12] Li, X., G. Lope, Tabi and S. Panigrahi. 2007. Chemical Treatments of Natural Fiber for Use in Natural Fiber-Reinforced Composites: A Review, J. Polym. Environ, $15,25-33$.

[13] Lee, E.K., and S.Y. Choi. 2007. Preparation and Characterization of Natural Rubber Foams: Effects of Foaming Temperature and Carbon Black Content, J. Chem. Eng., 24 (6), 1070-1075.

[14] Feldman, D., and A.J. Hartomo. 1995. Bahan Polimer Konstruksi Bangunan, PT Gramedia Pustaka Utama, Jakarta.

[15] Stevens, M.P., and L. Sopyan. 2007. Kimia Polimer, Pradnya Paramita, Jakarta.

[16] Sudirman, Ridwan, Mujamilah, and W. Trijono. 2000, Analisis Termal and Struktur Mikro Magnet Komposit Berbasis Heksaferit dengan Matriks Karet Alam, Jurnal Sains Material Indonesia, 2 (1), 1317. 
Cord 2013, 29 (1) 